\title{
ResearchArticle
}

\section{Genetic variability and heritability studies on bread wheat (Triticum aestivum L.)}

\author{
GOVIND PATI TRIPATHI, N.S. PARDE, D.K.ZATE AND GAIBRIYAL M. LAL
}

\begin{abstract}
SUMMARY
Genetic variability was studied in thirty diverse genotypes of wheat evaluated during Rabi season of 2007-2008 under agro climatic conditions of Allahabad. The study revealed highly significant differences for all the characters studied, indicating the presence of substantial genetic variability. The phenotypic and genotypic co-efficient of variation (PCV and GCV) was moderate high for tiller per plant followed by grain yield per plant and biological yield per plant. While the heritability was found to be highest in plant height followed by days to 50 per cent flowering, strove yield per plant, number of grains per spike, test weight and grain yield per plant. High heritability coupled with high genetic advance was observed in plant height, strove yield and harvest index which indicates the presence of good amount of variability for these traits.
\end{abstract}

Key Words : Genetic variability, Heritability, Genetic advance, Triticum aestivum L.

How to cite this article : Tripathi, Govind Pati, Parde, N.S., Zate, D.K. and Lal, Gaibriyal M. (2015). Genetic variability and heritability studies on bread wheat (Triticum aestivum L.). Internat. J. Plant Sci., 10 (1): 57-59.

Article chronicle : Received : 19.10.2014; Revised : 24.11.2014; Accepted : 10.12.2014

\section{MEMBERS OF THE RESEARCH FORUM}

Author to be contacted :

N.S. PARDE, Department of Agricultural Botany, College of Agriculture, Golegaon, HINGOLI (M.S.) INDIA

Address of the Co-authors:

D.K. ZATE, Department of Agricultural Botany, College of Agriculture, Golegaon, HINGOLI (M.S.) INDIA

GOVIND PATI TRIPATHI AND GAIBRIYAL M. LAL, Department of Genetics and Plant Breeding, Sam Higginbottom Institute of Agriculture Technology and Sciences, ALLAHABAD (U.P.) INDIA 